\title{
PENERAPAN TRANSPARANSI, AKUNTABILITAS, SERTA KESESUAIANNYA PADA LAPORAN KEUANGAN UMKM DI KOTA SEMARANG
}

\author{
Dheasey Amboningtyas ${ }^{1}$, Rita Andini², Djamaludin Malik ${ }^{3}$ \\ Universitas Pandanaran Semarang \\ Email: dheasey@unpand.ac.id ${ }^{1)}$ \\ ritaandini007@ymail.com ${ }^{2}$ \\ malik_djamal@yahoo.co.id ${ }^{3)}$
}

\begin{abstract}
Keywords: Abstract
Small and Medium

Micro, Small and Medium Enterprises (MSMEs) are one of the crucial aspects of the economy in the region and in the country, including in Enterprises (MSMEs), Financial Reports, Transparency, and Accountability Indonesia. MSMEs are able to provide substantial employment opportunities, thus providing opportunities for MSMEs to be able to develop and compete. UMKM has a quite large role in improving the domestic economy, this is evident through the contribution made to Indonesia's Gross Domestic Product (GDP). MSMEs often neglect their financial records and reporting, because they are more focused on operational activities. Financial statements have a crucial role, in addition to being a consideration for business owners in making decisions, as well as to get a picture of the company's financial performance, profit or loss, so that business actors can make plans in the future so that the business is more developed. This research was conducted to find out how to understand, apply and model the implementation of financial statement writing in accordance with Transparency and Accountability. Retrieval of data using purposive sampling method which is then tested using SEM analysis tools. The results of the research that has been done, there is a conformity that is expected in SMEs.
\end{abstract}

Kata Kunci:

Usaha Kecil dan Menengah (UMKM), Laporan Keuangan,

Transparansi, dan Akuntabilitas.

\begin{abstract}
Abstrak
Usaha Mikro Kecil dan Menengah (UMKM) menjadi salah satu aspek yang krusial dalam perekonomian dalam daerah maupun Negara, tidak terkecuali di Indonesia. UMKM mampu menyediakan lapangan kerja yang cukup besar, sehingga memberikan kesempatan bagi UMKM untuk dapat berkembang dan bersaing. UMKM memiliki peranan cukup besar di dalam peningkatan ekonomi dalam negeri, hal ini terbukti melalui kontribusi yang diberikan terhadap Produk Domestik Bruto (PDB) Indonesia. UMKM seringkali mengabaikan pencatatan dan pelaporan keuangan mereka, dikarenakan lebih fokus pada kegiatan operasional semata. Laporan keuangan memiliki peran yang krusial, selain sebagai pertimbangan bagi pemilik usaha dalam mengambil keputusan, juga untuk mendapatkan gambaran kondisi kinerja keuangan perusahaan, untung atau rugi, sehingga pelaku usaha dapat membuat rencana kedepannya agar usahanya lebih berkembang. Penelitian ini dilakukan untuk mengetahui bagaimana pemahaman, penerapan serta model implementasi penulisan laporan keuangan yang sesuai dengan Transparansi dan Akuntabilitas. Pengambilan data menggunakan metode purposive sampling yang kemudian data diuji dengan alat analisis SEM. Hasil dari pengkajian yang telah dilakukan, terdapat kesesuaian yang diharapkan di UMKM..
\end{abstract}




\section{PENDAHULUAN}

\section{Latar Belakang}

Dalam usaha untuk pertumbuhan ekonomi masyarakat, UMKM memiliki pengaruh yang besar pada Negara-negara yang masih berkembang. UMKM memiliki pengaruh positif untuk meningkatkan perekonomian di Indonesia dan menyediakan lapangan kerja dengan jumlah yang cukup besar. UMKM memiliki kemampuan untuk menyediakan lapangan kerja guna mengatasi masalah pengangguran dan pengentasan kemiskinan. Pengaruh tersebut dapat dilihat dari tinggginya tenaga kerja yang terserap dari sektor UMKM. Eksistensi UMKM sebagai tumpuan ekonomi, pada masa darurat ekonomi, UMKM tidak diragukan lagi karena ternyata sanggup bertahan ketika terjadi krisis ekonomi. Jumlah pengangguran semakin berkurag seiring dengan perkembangan jumlah unit usaha kecil menengah yang terus meningkat.

UMKM berperan besar terhadap perkembangan perdagangan di Indonesia, dilihat dari kontribusinya terhadap PDB yang semakin meningkat setiap tahunnya. Bertambahnya jumlah UMKM memberikan peran yang sangat penting bagi pelaku kewirausahaan. Pengalaman di Negara negara yang sudah maju terbukti bahwa UMKM bisa menjadi sumber dari pembaruan produksi dan teknologi, meningkatnya jumlah enterpreneur yang produktif dan inovatif dalam menciptakan SDM yang mahir dan luwes dalam menjalankan metode produksi guna menghadapi pergantian permintaan pasar yang selalu berubah-ubah (Nurhidayati, 2013).

Selain jumlah UMKM yang selalu meningkat setiap tahunnya, hal yang perlu dicermati adalah jumlah peningkatan dan tenaga kerja yang terserap oleh pertumbuhan unit UMKM di Indonesia. UMKM menjadi tumpuan dasar pembangunan perekonomian di Indonesia. UMKM juga memiliki peran penting dalan mengurangi pengangguran, seperti contoh pada tahun 2015 UMKM menyerap tenaga kerja sekitar 97 persen dari jumlah tenaga kerja nasonal dan menyumbang 57 persen ke PDB. Tahun 2016 UMKM berkontribusi terhadap PDB sebebsar 60,34 persen. Oleh karena itu seharusnya keberadaan UMKM lebih diperhatikan oleh pemerintah dan masyarakat agar mampu berkontribusi lebih maksimal terhadap peningkatan ekonomi dan kesejahteraan masyarakat.

Pencapaian yang luar biasa dan potensi yang besar dari UMKM tersebut seringkali menghadapi kendala atau masalah yang disebabkan banyak UMKM yang lebih fokus pada kegiatan operasional saja dan mengabaikan pencatatan dan pelaporan keuangan mereka. Kunci keberhasilan dalam menjalankan usaha adalah dengan menerapkan laporan keuangan. seorang akuntan menjalankan laporan keungan dengan sedemikian rupa dengan sangat rapi dalam perusahaan berskala besar maupun kecil. Sebab laporan berfungsi sebagai sumber informasi untuk menghitung laba rugi, tetapi juga sebagai pertimbanga dalam merencanakan persaingan bisnis. Laporan keuangan sekaligus juga sebagai tanda kewajiban dalam pelaporan pajak.

Laporan keuangan merupakan sebagian kecil dari metode informasi yang digunakan dalam kehidupan ekonomi, khususnya bidang keuangan. Fungsi laporan keuangan adalah menyediakan laporan yang bersifat keuangan mengenai entitas ekonomi yang dapat bermanfaat untuk mengambil keputusan. Pengelolaan keuangan UMKM berperan penting dalam proses peningkatan kualitas UMKM . Masih banyak pengusaha yang belum melakukan pencatatan pemasukan dan pengeluaran UMKM yang 
Dheasey Amboningtyas

Rita Andini

Djamaludin Malik
Penerapan Transparansi , Akuntabilitas, Serta Kesesuaiannya Pada Laporan Keuangan Umkm Di Kota Semarang

menggunakan informasi dalam laporan keuangan untuk mengevaluasi usahanya dan dapat dijadikan dasar dalam pengambilan keputusan.

\section{Rumusan Masalah}

Dari uraian latar belakang, maka perumusan masalah dalam pengkajian ini adalah :

1. Apakah penerapan rincian keuangan yang berbasis SAK ETAP sudah cukup efisien untuk menjadikan UMKM lebih kompetitif ?

2. Bagaimana pembuatan laporan keuangan yang efisien guna meningkatkan rivalitas UMKM ?

\section{Tujuan Penelitian}

Berdasarkan perumusan masalah yang telah ditetapkan, tujuan dari penelitian ini adalah:

1. Untuk mengetahui apakah penerapan rincian keuangan berbasis SAK ETAP sudah cukup efisien untuk menjadikan UMKM lebih kompetitif.

2. Untuk mengetahui bagaimana pembuatan laporan keuangan yang efisien guna meningkatkan rivalitas UMKM.

\section{Telaah Pustaka}

\section{Usaha Mikro Kecil Menengah (UMKM)}

Usaha mikro Kecil dan Menengah (UMKM) adalah lembaga yang memiliki entrepreneurial organization berperan penting dalam kemajuan ekonomi suatu negara maupun daerah. Kerjasama ekonomi antar negara terutama dalam konteks ASEAN yang semakin pesat, mendorong pertumbuhan ekonomi dunia semakin tinggi sehingga menciptakan peluang baru bagi UMKM. Perkembangan UMKM yang semakin pesat menunjang kegiatan perekonomian Negara, karena UMKM mampu meningkatkan produktivitas ekonomi suatu Negara melalui investasi dan mampu mengatasi masalah 
pengangguran, agar dapat meminimalkan angka kemiskinan.

\section{Laporan Keuangan}

Menurut Harahap (2008) Laporan keuangan mengilustrasikan situasi keuangan dan hasil bisnis suatu perusahaan pada saat tertentu atau masa waktu tertentu. Laporan keuangan berisi catatan informasi keuangan yang dapat memberikan manfaat bagi perusahaan maupun stakeholder dalam mengambil kepastian di masa mendatang. Laporan keuangan yang lengkap biasanya meliputi neraca, laporan laba rugi, laporan perubahan ekuitas, laporan perubahan posisi keuangan, laporan arus kas dan catatan atas laporan keuangan. Laporan keuangan disusun dengan tujuan agar pemakai dapat melihat bagaimana manajemen melaporkan pertanggungjawaban atas sumber daya yang diberikan. Melalui laporan tersebut mereka dapat memutuskan untuk menahan atau menjual pendanaan yang telah diberikan, atau mengganti dengan manajemen yang baru.

\section{Standar Akuntansi Keuangan Entitas Tanpa Akuntabilotas Publik (SAK ETAP)}

SAK ETAP merupakan Standar Akuntasi yang ditujukan bagi entitas yang perincian keuangannya tidak terbuka untuk umum secara luas (Amri F, 2016). Penggunaan SAK ETAP ditujukan untuk entitas tanpa akuntabilitas publik yang tidak signifikan dan entitas yang mengeluarkan rincian keuangan untuk tujuan umum pengguna eksternal. Dengan adanya penerapan SAK ETAP diharapkan pelaku UMKM mampu untuk menyusun laporannya sendiri sehingga dapat menggunakan laporan tersebut untuk mendapatkan dana atau investasil untuk kemajuan bisnisnya.

\section{Kerangka Pemikiran Teoritis}

Berdasarkan analisis tentang analisis pencatatan laporan keuangan berbasis Standar Akuntansi Keuangan Entitas Tanpa Akuntanbilitas Publik (SAK ETAP) pada Usaha Kecil Menengah (UMKM) yang telah ditetapkan dalam landasan teori yang nantinya akan diuji untuk menentukan kesimpulan, maka dibuat alur pemikiran sebagai berikut :

\section{Gambar 01 Kerangka Pemikiran}

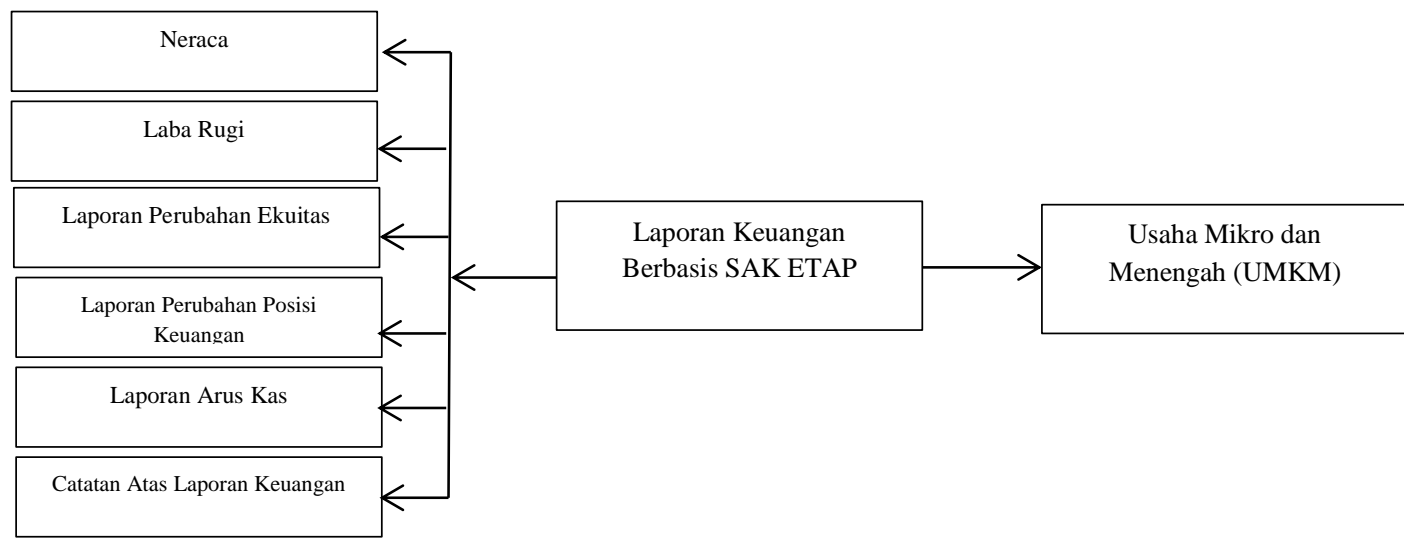

Sumber : dikembangkan dari penelitian terdahulu, 2019

Hipotesis Penelitian

Menurut Sugiyono (2015) menyatakan bahwa hipotesis merupakan asumsi sementara terhadap rumusan masalah dalam pengkajian, dimana rumusan masalah pengkajian telah dinyatakan dalam bentuk perkataan tanya. Berdasarkan model yang digunakan tersebut diatas, maka 
Dheasey Amboningtyas

Rita Andini

Djamaludin Malik

asumsi yang diusulkan dalam penelitian ini adalah :

H1 : penerapan perincian keuangan yang berbasis SAK ETAP sudah cukup efisien untuk menjadikan UMKM lebih kompetitif

$\mathrm{H} 2$ : cara pembuatan laporan keuangan yang efisien untuk meningkatkan rivalitas UMKM

\section{Metode Penelitian}

Variabel Penelitian

Menurut Sugiyono (2015) variabel penelitian adalah suatu atribut, karakter atau ukuran dari orang, sasaran atau tindakan yang mempunyai perbedaan tertentu yang kemudian ditetapkan oleh pengkaji untuk diamati dan ditarik kesimpulannya. Terdapat dua jenis variabel pada penelitian ini, yaitu : variabel dependen dan independen. Variabel independen biasa disebut sebagai variabel stimulus, atau predictor (Sugiyono, 2015). Variabel dependen sering disebut sebagai variabel keluaran, kriteria atau konsekuen (Sugiyono, 2015). Variabel dalam dependen dalam pengkajian ini adalah perincian laporan keuangan yang berbasis SAK ETAP pada UMKM Di Wilayah Kota Semarang.

\section{Jenis dan Sumber Data}

Jenis data yang digunakan dalam penelitian ini merupakan data kuantitatif yakni data yang diukur dalam suatu skala numerik (angka). Sumber data terdiri atas dua macam yaitu data primer dan data sekunder. Data primer khusus dan berhubungan langsung dengan permasalahan yang diteliti (Emory and Cooper, 2010). Sumber data untuk penelitian ini diperoleh secara langsung dari pengisian daftar pertanyaan oleh responden yaitu Usaha Mikro Kecil dan Menengah (UMKM) di kota Semarang melalui wawancara langsung oleh tim surveyor lapangan.
Penerapan Transparansi , Akuntabilitas, Serta Kesesuaiannya Pada Laporan Keuangan Umkm Di Kota Semarang

\section{Populasi dan Sampel}

Seluruh UMKM dari berbagai sektor ekonomi yang ada di wilayah kota Semarang dijadikan populasi dalam pengkajian ini. Pengambilan data dengan cara purposive sampling, yaitu suatu cara pengumpulan data yang bertujuan data yang dipulangkan saja yang akan diolah melalui elemen atau anggota populasi secara menyeluruh. Pertimbangan dalam penggunaan tata cara ini dikarenakan keterbatasan jumlah pemilik yang dapat dijadikan sebagai responden. Dikarenakan pengkaji belum mengetahui dari total sampel yang dikirimkan berapa jumlah yang akan kembali, maka seluruh populasi sejumlah 150 UMKM akan digunakan sebagai sampel dan data yang kembali merupakan data yang akan diolah.

\section{Metode Pengumpulan Data}

Teknik pengumpulan data yang digunakan dalam pengkajian ini adalah angket atau kuesioner. Kuesioner/angket adalah kumpulan persoalan yang diberikan kepada responden yang bersedia memberikan jawaban sesuai dengan yang diharapkan oleh pengkaji (Arikunto, 2013). Kuesioner adalah metode pengumpulan data dengan cara membagikan atau mengirimkan

kumpulan persoalan/pernyataan kepada responden dengan tujuan responden memberikan respon atas pertanyaan tersebut.

\section{Metode Analisis}

\section{Uji Instrumen}

Uji instrumen data pengkajian ini dapat dinilai melalui uji reliabilitas (pengujian konsisten internal) dan uji Validitas (validity). Pengujian tersebut masing-masing untuk mengetahui konsistensi dan ketepatan data yang digabungkan dari penggunaan instrument. Prosedur yang dilakukan dalam pengkajian ini guna mengukur kualitas data digunakan dua uji yaitu : 


\section{Uji Validitas}

Arikunto, (2013) menerangkan bahwa validitas adalah merupakan patokan yang menunjukkan tingkat atau keabsahan suatu pernyataan. pernyataan yang valid menunjukan alat ukur yang dipakai untuk menghasilkan data itu valid dan dapat dipakai untuk menunjukan apa yang seharusnya dikaji. Suatu pernyataan yang valid memiliki validitas yang tinggi, dan sebaliknya pernyataan yang kurang valid memiliki validitas yang rendah.

Penelitian ini menggunakan pengujian validitas konstrak (construct validity). Untuk menguji validitas konstrak, instrumen yang telah disusun sesuai aspekaspek yang akan diukur berdasarkan teori.

\section{Uji Reliabilitas}

Reliabilitas merupakan suatu instrumen dapat diakui untuk dipakai sebagai sarana pengumpul data karena instrumen sudah baik (Arikunto, 2013). Instrumen yang reliabel adalah instrumen yang jika digunakan beberapa kali untuk mengukur sasaran yang serupa, akan menghasilkan data yang sama. Dalam penelitian ini pengujian reliabilitas yang digunakan adalah rumus Cronbach's Alpha. Rumus Cronbach's Alpha ini digunakan untuk mencari instrumen yang jika instrumen pengukuran sistem penskorannya bukan 1 dan 0 , tetapi penjenjangan skor (skala).

\section{Metode Analisa}

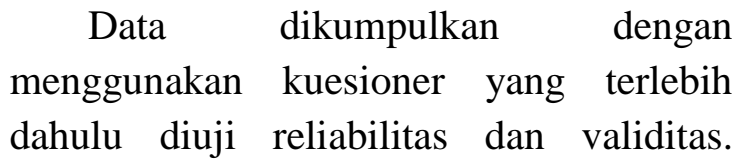
Pengkajian tersebut untuk mengetahui konsistensi dan kebenaran data yang diamati melalui penggunaan instrument. Selanjutnya asumsi dikaji menggunakan analisis jalur (path analysis) atau analisis Structural Equation Modeling (SEM). Structural Equation Modelling (SEM) merupakan sebuah metode untuk mengukur suatu variabel yang variabelnya tidak dapat diukur secara langsung. Untuk pengkajian yang bertujuan mencari ramalan dalam situasi kompleksitas yang tinggi dan berprinsip pada teori yang rendah, hipotesis pertama dan kedua akan dijawab dengan menggunakan parameter Partial Least Square (PLS). PLS dipakai untuk mengetahui interaksi suatu konstrak dan parameternya untuk mengetahui kompleksitas hubungan tersebut.

\section{HASIL DAN PEMBAHASAN}

\section{Statistik Deskriptif}

Dalam pengujian ini deskripsi variabel bertujuan untuk mengetahui gambaran responden terhadap masing-masing pertanyaan yang menjadi instrument penelitian. Dalam hal ini peneliti dapat mengetahui melalui gambaran tanggapan responden terhadap variabel-variabel yang dikaji, sehingga dapat diketahui intensitas keadaan tiap-tiap variabel.

\section{Uji Instrumen}

Evaluasi pengukuran outer model menggunakan uji Partial Least Square (PLS) yaitu suatu teknik statistik multivariat yang bisa untuk menangani banyak variabel respon serta variabel eksplanatori sekaligus.. Adapun pengujian tersebut akan diuraikan sebagai berikut :

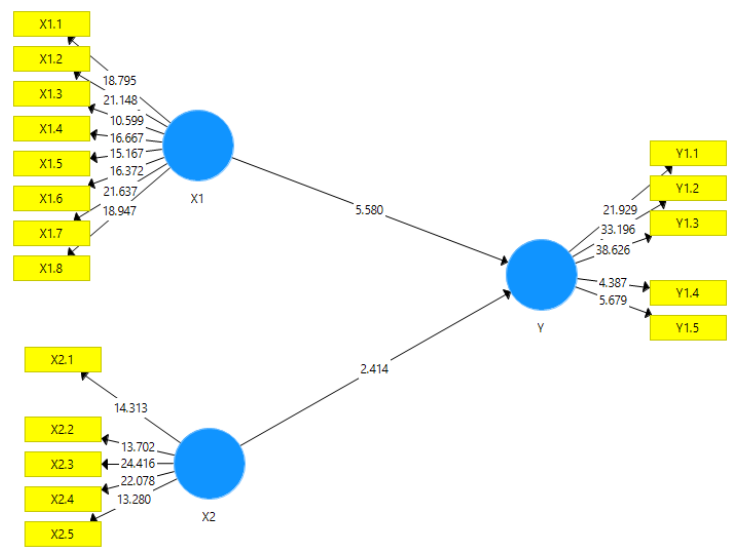

Gambar 2 Hasil Pengujian Kelayakan

Structural Equation Modeling (SEM)

Hasil Outer Model (Measurement Model) Uji Convergent Validity 
Dheasey Amboningtyas

Rita Andini

Djamaludin Malik
Penerapan Transparansi , Akuntabilitas, Serta Kesesuaiannya Pada Laporan Keuangan Umkm Di Kota Semarang
Validitas konvergen digunakan untuk menghitung kesahihan suatu indikator refleksif sebagai alat ukur variabel yang terlihat dari outer loading dari tiap-tiap indikator variabel. Jika nilai outer loding di atas 0,70 Instrumen dikatakan mempunyai kesahihan atau keabsahan yang baik (Sarwono, 2015). Nilai outer loading yang masih dapat diterima adalah 0,50 dan dibawah dari nilai 0,50 dapat dikeluarkan dari analisis (Ghozali, 2015).

Tabel 1 Hasil Outer Loadings

\begin{tabular}{ccccc}
\hline Indikator & Skor Variabel Laten & T Statistik & Batas Loading & Keterangan \\
\hline X1.1 & 0.768 & 17.712 & $0.5-0.6$ & Valid \\
X1.2 & 0.738 & 21.389 & $0.5-0.6$ & Valid \\
X1.3 & 0.630 & 9.477 & $0.5-0.6$ & Valid \\
X1.4 & 0.740 & 15.314 & $0.5-0.6$ & Valid \\
X1.5 & 0.736 & 13.627 & $0.5-0.6$ & Valid \\
X1.6 & 0.701 & 15.841 & $0.5-0.6$ & Valid \\
X1.7 & 0.777 & 22.735 & $0.5-0.6$ & Valid \\
X1.8 & 0.757 & 19.150 & $0.5-0.6$ & Valid \\
X2.1 & 0.741 & 13.582 & $0.5-0.6$ & Valid \\
X2.2 & 0.721 & 11.936 & $0.5-0.6$ & Valid \\
X2.3 & 0.815 & 22.325 & $0.5-0.6$ & Valid \\
X2.4 & 0.822 & 19.602 & $0.5-0.6$ & Valid \\
X2.5 & 0.684 & 12.552 & $0.5-0.6$ & Valid \\
Y1.1 & 0.797 & 21.390 & $0.5-0.6$ & Valid \\
Y1.2 & 0.876 & 33.315 & $0.5-0.6$ & Valid \\
Y1.3 & 0.866 & 36.332 & $0.5-0.6$ & Valid \\
Y1.4 & 0.571 & 4.630 & $0.5-0.6$ & Valid \\
Y1.5 & 0.550 & 5.639 & $0.5-0.6$ & Valid \\
\hline
\end{tabular}

Sumber : Hasil Olahan PLS, 2019

Dari hasil penelitian dapat dilihat bahwa cross loading antara indikator dengan konstruk pengukur variabel bernilai lebih besar dari $0,50-0,60$. Hal ini menunjukan setiap indikator mempunyai reabilitas yang baik dan layak untuk dilanjutkan dalam penelitian.

\section{Discriminant Validity}

Kriteria untuk pengukuran discriminant validity pada tiap konstruk dengan hubungan antara konstruk dengan konstruk lainnya dalam model adalah dengan membandingkan dari Average Variance Extracted (AVE). jika nilai AVE untuk setiap konstruk lebih besar dari pada korelasi antara konstruk konstruk lainnya artinya model mempunyai discriminant validity yang cukup.

Tabel 2

Hasil Discriminant Validity Average Variance Extracted (AVE)

\begin{tabular}{cr}
$\mathbf{X 1}$ & 0.536 \\
$\mathbf{X} 2$ & 0.575 \\
$\mathbf{Y}$ & 0.535 \\
\hline
\end{tabular}

Berdasarkan hasil uji discriminant validity terlihat bahwa AVE konstruk pada masing-masing variabel menunjukan nilai AVE telah melebihi dari ketenuan sebesar 0,5 sehingga dapat disimpulkan bahwa nilain konstruk pada variabel penelitian tersebut memiliki nilai discriminant validity yang baik.

\section{Composite Reliability}


Composite Reliability digunakan untuk mengukur reliabilitas konstruk. Composite reliability mencerminkan reliabel jika semua indikator dalam model mempunyai besaran nilai minimal ialah 0,7 .

\section{Tabel 4.3}

\section{Hasil Composite Reliability}

\begin{tabular}{ccc}
\hline Variabel & $\begin{array}{c}\text { Composite } \\
\text { Reliability }\end{array}$ & Kriteria \\
\hline X1 & 0.902 & 0,7 \\
X2 & 0.871 & 0,7 \\
Y & 0.845 & 0,7 \\
\hline
\end{tabular}

Sumber : Hasil Olahan PLS, 2019

Pada tabel 4.3 menunjukan nilai composite reliability seluruh indikator variabel lebih besar dari nilai standarisasi sebesar 0,70 , yang artinya semua indikator dalam model dapat digunakan untuk mengungkapkan data yang sebenarnya dari suatu objek.

\section{Hasil Inner Model}

Penelitian ini menggunakan teknik Structural Equation Model (SEM) dengan menggunakan metode PLS, yang berfungsi untuk mengetahui penerapan transparansi dan akuntabilitas serta kesesuaiannya pada laporan keuangan UMKM. Hasil pengujian diperoleh hasil sebagai berikut :

\section{Tabel 4.4}

\section{Persamaan Jalur Partial Least Square} (PLS)

\begin{tabular}{ccccc}
\hline & $\begin{array}{c}\text { Original } \\
\text { Sample }\end{array}$ & $\begin{array}{c}\text { Sample } \\
\text { Mean }\end{array}$ & $\begin{array}{c}\text { Standard } \\
\text { Deviation }\end{array}$ & $\begin{array}{c}\text { T } \\
\text { Statistics }\end{array}$ \\
\hline $\mathbf{X 1 ~} \rightarrow \mathbf{Y}$ & 1.020 & 1.006 & 0.184 & 5.530 \\
$\mathbf{X 2} \rightarrow \mathbf{Y}$ & -0.463 & -0.435 & 0.192 & 2.417 \\
\hline \multicolumn{4}{c}{ Sumber : Hasil Olahan PLS, 2019}
\end{tabular}

Hasil persamaan jalur model diatas dapat diinterpretasikan sebagai berikut :

1. Nilai original sample untuk variabel X1 terhadap Y mempunyai nilai parameter positif yaitu sebesar 1,020 memberikan pengertian bahwa semakin tinggi penerapan pengelolaan keuangan, maka mampu menciptakan laporan keuangan yang semakin transparan sehingga mampu meningkatkan daya saing UMKM dalam melakukan usaha.

2. Nilai original sample untuk variabel $\mathrm{X} 2$ terhadap Y mempunyai nilai parameter negatif yaitu sebesar -0,463 memberikan pengertian bahwa semakin tinggi penerapan pengelolaan keuangan, maka pertanggungjawaban dalam menciptakan laporan keuangan semakin tinggi, maka jika penanggung jawab laporan keuangan tidak kompeten malah akan memperburuk nilai transparansi laporan keuangan sehingga dapat menghambat daya saing UMKM.

\section{Pengujian Hipotesis}

Pengujian hipotesis merupakan pengujian yang menjelaskan pengaruh keterikatan variabel independen terhadap variabel dependen.

Tabel 4.5

\begin{tabular}{|c|c|c|}
\hline Persamaan J & $\begin{array}{l}\text { Partial Le } \\
\text { (PLS) }\end{array}$ & t Square \\
\hline $\begin{array}{l}\text { Sumber } \\
\text { - Hasil }\end{array}$ & T Statistics & P Values \\
\hline $\mathrm{X} 1$-> Y & 5.530 & 0.000 \\
\hline $\begin{array}{l}\text { PLS, } \quad \mathbf{X} 2 \text {-> Y } \\
2019\end{array}$ & 2.417 & 0.016 \\
\hline
\end{tabular}

1. Berdasarkan hasil pengujian, penerapan laporan keuangan yang berbasis SAK ETAP pada UMKM diperoleh hasil nilai T statistik sebesar 5,530 sehingga telah melebihi dari nilai $\mathrm{T}$ tabel sebesar 1,96, artinya bahwa penerapan laporan keuangan yang berbasis SAK ETAP mempunyai pengaruh yang signifikan terhadap daya saing UMKM. Berdasarkan hasil pengujian dapat disimpulkan bahwa pengujian tersebut mampu menerima $\mathrm{H} 1$,sehingga dugaan penerapan perincian keuangan berbasis SAK ETAP sudah cukup efisien untuk menaikan daya saing UMKM terbukti atau dapat diterima.

2. Berdasarkan hasil pengujian, cara pembuatan laporan keuangan yang 
berbasis SAK ETAP diperoleh hasil nilai $\mathrm{T}$ statistik sebesar 2,417 sehingga telah melebihi dari nilai T tabel sebesar 1,96, artinya bahwa cara pembuatan laporan keuangan yang berbasis SAK ETAP mempunyai pengaruh yang signifikan terhadap daya saing UMKM. Berdasarkan hasil pengujian dapat disimpulkan bahwa pengujian tersebut mampu menerima $\mathrm{H} 2$,sehingga cara pembuatan perincian keuangan berbasis SAK ETAP yang efisien untuk menaikan daya saing UMKM terbukti atau dapat diterima.

\section{R Square}

$R$ square berfungsi untuk mengetahui seberapa besar variabel dependen mampu dijelaskan oleh variabel independen. Berikut hasil pengujiannya :

\section{Tabel 4.6}

\section{Nilai R-Square}

\begin{tabular}{ccc}
\hline & R Square & R Square Adjusted \\
\hline Y & 0.355 & 0.346 \\
\hline & Sumber : Hasil Olahan PLS, 2019
\end{tabular}

Berdasarkan tabel 4.6 menunjukan bahwa pengaruh indikator variabel $\mathrm{X} 1$ dan $\mathrm{X} 2$ memberi nilai sebesar 0,355 yang dapat diinterpretasikan bahwa variabel konstruk independensi dapat dijelaskan oleh variabel konstruk cara pengelolaan keuangan dan bentuk keuangan efisien sebesar 35,5\%, sedangkan sisanya $64,55 \%$ dijelaskan oleh variabel lain diluar yang diteliti.

\section{PENUTUP}

\section{Kesimpulan}

Kesimpulan yang dapat diambil dari hasil penelitian pada UKM di Kota Semanrang adalah sebagai berikut :

1. Implementasi perincian keuangan yang berbasis SAK ETAP berpengaruh signifikan terhadap tingkat kompetitif UMKM di kota Semarang. Hal ini memberikan pengertian bahwa perincian keuangan berbasis SAK ETAP akan mampu menciptakan laporan keuangan yang lebih baik sehingga dapat digunakan untuk menentukan langkah dan strategi UMKM untuk kedepannya agar dapat meningkatkan daya saingnya.

2. Cara pembuatan laporan keuangan yang berbasis SAK ETAP agar lebih efisien berpengaruh signifikan terhadap tingkat kompetitif UMKM di kota Semarang. Hal ini memberikan pengertian UMKM yang mengetahui cara pembuatan perincian keuangan berbasis SAK ETAP yang efisien akan menghasilkan catatan laporan keuangan yang lebih lengkap dan transparan. UMKM dapat menggunakan laporan keuangan tersebut untuk mencari stakeholder agar berinvestasi pada UMKM mereka, sehingga mereka dapat lebih mengembangkan usaha dan meningkatkan daya saingnya.

\section{Saran}

Dalam pengerjaan rincian keuangan yang sesuai dengan SAK ETAP pasti ditemukan kendala-kendala dalam proses penyusunannya, oleh karena itu diharapkan UMKM untuk :

1. Pengelola UMKM secara rutin meluangkan waktu untuk mencatat setiap transaksi dalam jurnal.

2. Mendokumentasikan lampiranlampiran transaksi pembelian maupun penjulan dengan seksama agar pada saat pencatatan tidak ada bukti transaksi yang hilang.

3. Menyediakan fasilitas yang mendukung dalam penyusunan laporan keuangan, misalnya komputer dan aplikasi pendukungnya.

\section{DAFTAR PUSTAKA}

Agus Harjito \& Martono. 2012. Manajemen Keuangan Edisi Kedua. Yogyakarta : Ekonisia 
Amri Nur F. 2016. Standar Entitas Keuangan Entitas Tanpa Akuntanbilitas Publik. Website https://www.eakuntansi.com/2015/09/s ak-etap.html diakses pada tanggal 15 April 2019 pukul 22.16 WIB.

Arikunto, S. 2013. Prosedur Penelitian : Suatu Pendekatan Praktik. Jakarta : Rineka Cipta.

Cooper dan Emory. 2010. Metode Penelitian Bisnis. Jakarta : Erlangga

Ghozali, 2015. Aplikasi Analisis Multivariate dengan Program SPSS. Semarang : Universitas Diponegoro.

Ghibran, 2013. Pengertian Laporan Keuangan. Website http://gibrandeleonardo.blogspot.co.id /2013/04/pengertian-laporankeuangan.html diakses pada tanggal 15 April 2019 pukul 20.33 WIB.

Harahap, Sofyan, Syafri. 2013. Analisis Kritis Atas Laporan Keuangan. Jakarta : Raja Grafindo Persada

Ikatan Akuntan Indonesia. 2013. Standar Akuntansi Keuangan Entitas Tanpa Akuntabilitas Publik: Jakarta.

Kuncoro, M., 2013. Metode Riset Untuk Bisnis \& Ekonomi: Bagaimana Meneliti \& Menulis Tesis? Cetakan 1, Edisi Revisi. Jakarta : Erlangga

Lyn M. Fraser \& Aileen Ormiston. 2010. Memahami Laporan Keuangan, diterjemahkan oleh Setyautama. Jakarta : Indeks

Neneng S.Indarti dan Fitri S. 2015 Analisis Penerapan Akuntansi Dan Kesesuaiannya Dengan Standar Akuntansi Keuangan Entitas Tanpa Akuntabilitas Public (Pada UMKM Di Kecamatan Sukajadi Binaan Diskop \& UMKM Kota Pekanbaru). Jurnal Ekonomi Vol.3 No. 2 Hal 212-226. Universitas Lancing Kuning.
Nurita dan Rustam, 2016. Analisis Faktor Yang Memperngaruhi Penerapan Standar Akuntansi Keuangan Entitas Tanpa Akuntanbilitas Public (SAK ETAP) Pada Usaha Mikro Kecil Dan Menengah (UMKM). Jurnal Ekonomi Vol. 5 No.1 Hal 79-98 Universitas Semarang.

Rahmana, Arief. 2010. Usaha Kecil dan Menengah (UMKM), Informasi Terdepan tentang Usaha Kecil Menengah, (online), (http://infoUMKM.wordpress.com, diakses 15 April 2019)

Rivai,V. 2014. Bank And Financial Institute Management. Jakarta : Raja Grafindo Persada

Sariningtyas, Pratiwi dan Diah, W Tituk. 2012. Standar Akuntansi Keuangan Entitas Tanpa Akuntabilitas Publik pada Usaha Kecil dan Menengah. Vol.1. No. 1.

Sarwono, J. 2015. Membuat Skripsi, Tesis dan Disertasi dengan Partial Least Square SEM (PLS-SEM). Yogyakarta : ANDI.

Sugiyono. 2015. Memahami Penelitian Kualitatif. Bandung: Alfabeta

Undang-Undang Republik Indonesia No.9 Tahun 1995. Tentang Usaha Kecil.

Undang-Undang Republik Indonesia No.20 Tahun 2008. Tentang Koperasi dan UMKM 